\title{
Ropivacaine combined with various anti-arrhythmic drugs results in mild alterations in myocardial contractility in pigs
}

\author{
[La ropivacaïne, combinée à divers médicaments anti-arythmiques, provoque de \\ légères modifications de la contractilité myocardique chez le porc]
}

Cécile Barel MD, ${ }^{*} \dagger$ Majda Belkhiria PHARM D, ${ }^{\star} \ddagger$ Bernard Bui-Xuan MD PhD, $\$$ Jacques Descotes MD PhD, ${ }^{*}$ Philippe Chevalier MD PhD, II Marie-Claude Gagnieu PhD, Florence Arnal, * Panayota Tsibiribi, ${ }^{*}$

Quadiri Timour $\mathrm{PhD}^{*}$

Purpose: The present study was undertaken following the observation of a marked decrease in myocardial contractility after ropivacaine in a patient on amiodarone, in order to investigate the cardiovascular effects of combining ropivacaine with anti-arrhythmic drugs (AARD).

Methods: Anesthetized domestic pigs were treated with disopyramide, flecainide, atenolol, amiodarone, diltiazem or nicardipine at a dose leading to blood levels obtained in treated patients, then received I $\mathrm{mg} \cdot \mathrm{kg}^{-1}$ ropivacaine. Blood pressure (BP), left venticular (LV) $\mathrm{dP} / \mathrm{dt}$ max, sinus heart rate, and intraventricular conduction time were measured before and following the administration of AARD, and following ropivacaine at different time points.

Results: All tested AARD induced the expected hemodynamic and electrophysiologic effects. Following ropivacaine, a 20 to $35 \%$ decrease in $\mathrm{LV} \mathrm{dP} / \mathrm{dt}$ max of prolonged duration was observed with amiodarone only. A brief 10 to $20 \%$ decrease in mean BP was observed in all animals, except those treated with nicardipine who sustained an important and prolonged decrease in BP. All other variables were not significantly affected.

Discussion: The combination of ropivacaine with AARD was always associated with a slight drop in LV dP/dt max. The effect on mean BP was slight, except with nicardipine. Clinicians should be aware of the interactions of ropivacaine with AARD, especially amiodarone and nicardipine.
Objectif : La présente étude, entreprise à la suite de l'observation d'une baisse marquée de la contractilité myocardique suivant l'administration de ropivacaïne chez un patient qui prenait de l'amiodarone, visait à rechercher les effets cardiovasculaires de la combinaison de ropivacaïne et de médicaments anti-arythmiques (MAAR).

Méthode : Des porcs domestiques anesthésiés ont été traités avec du disopyramide, du flécaïnide, de l'aténolol, de l'amiodarone, du diltiazem ou de la nicardipine selon des doses équivalentes aux niveaux sanguins atteints chez des patients traités, puis ils ont reçu I $\mathrm{mg} \cdot \mathrm{kg}^{-1}$ de ropivacaiine. La tension artérielle (TA), la dP/dt ventriculaire gauche (VG) maximale, la fréquence cardiaque sinusale et le temps de conduction intraventriculaire ont été mesurés avant et après l'administration de MAAR et après la ropivacaïne à différents moments de mesure.

Résultats : Tous les MAAR testés ont réduit les effets hémodynamiques et électrophysiologiques attendus. Après la ropivacaïne, une baisse de 20 à $35 \%$ de la dP/dt VG maximale de durée prolongée a été observée avec l'amiodarone seulement. Une brève chute de 10 to $20 \%$ de la TA moyenne a été notée chez tous les animaux, sauf chez ceux qui avaient reçu de la nicardipine, lesquels ont subi une baisse importante et prolongée de la TA. Aucune influence significative n'a été observée pour les variables restantes.

Conclusion : La combinaison de ropivacaïne et d'un MAAR était toujours associée à une légère baisse de la dP/dt VG maximale. L'effet sur la TA moyenne a été faible, sauf avec la nicardipine. Les cliniciens doivent connaitre les interactions de la ropivacaïne avec les MAAR, surtout l'amiodarone et la nicardipine.

From the Laboratory of Medical Pharmacology, ${ }^{*}$ Claude Bernard University, Lyon, France; the Department of Internal Medicine, $†$ Hôtel Dieu, Lyon, France; the Department of Pharmacology, $\ddagger$ Monastir, Tunis, Tunisia; the Department of Anesthesia and Resuscitation, $\$$ E.

Herriot Hospital, Lyon, France; the Department of Cardiology, Il Louis Pradel Hospital, Bron, France; and the Department of Biochemistry, E. Herriot Hospital, Lyon, France. Address correspondence to: Dr. Q. Timour, Laboratoire de Pharmacologie Médicale, 8, Avenue Rockefeller, 69373 Lyon cedex 08 ,

France. Phone: +33 4787771 88; Fax: +33 47877 71 85; E-mail: timour.quadiri@rockefeller.univ-lyonl.fr Assessed March 25, 2003.

lst revision accepted May 20, 2003.

2nd revision accepted August 11, 2003. 
$\mathrm{R}$ OPIVACAINE is widely used because its reduced diffusion and vasoconstricting properties result in lower blood levels and less toxic effects than with other local anesthetics, ${ }^{1}$ particularly bupivacaine. ${ }^{2}$ Following the observation of unexpected and severely impaired cardiac contractility evidenced by transthoracic echocardiography after local anesthesia with ropivacaine in one of our patients treated with amiodarone, the question arose of possible adverse interactions between ropivacaine and anti-arrhythmic drugs (AARD). This study was undertaken to investigate, in pigs, the hemodynamic and cardiac electrophysiological effects of combinations of ropivacaine with several AARD.

\section{Material and methods}

This randomized prospective study was approved by the local Animal Ethic's Committee. Domestic pigs (eight per group) weighting approximately $25 \mathrm{~kg}$ were anesthetized with midazolam $\left(0.1 \mathrm{mg} \cdot \mathrm{kg}^{-1} \mathrm{im}\right)$ and chloralose $\left(100 \mathrm{mg} \cdot \mathrm{kg}^{-1} \mathrm{iv}\right)$, tracheotomized and ventilated $\left(\mathrm{SAO}_{2}: 96 \%\right.$; PetCO $\left.2: 35 \mathrm{mmHg}\right)$. Blood pressure (BP) and left ventricular (LV) pressure were recorded continuously by catheters introduced via the carotid arteries and analyzed by the Acqknowledge ${ }^{\mathrm{TM}}$ software (Biopac System Inc., Santa Barbara, CA, USA) to obtain mean $\mathrm{BP}(\mathrm{mBP})$ and the peak of the time derivative of left ventricular pressure $(\mathrm{LV} \mathrm{dP} / \mathrm{dt}$ $\max$ ). Continuous electrocardiogram was computerized to measure sinus heart rate (HR), the PR, RR and QTc intervals, and duration of the QRS.

Six groups of pigs received one of the tested AARD plus ropivacaine, and one group ropivacaine alone. One AARD from each of Vaughan Williams' classes was tested, namely: disopyramide $\left(1.5 \mathrm{mg} \cdot \mathrm{kg}^{-1}\right)$, flecainide $\left(1.5 \mathrm{mg} \cdot \mathrm{kg}^{-1}\right)$, atenolol $\left(0.15 \mathrm{mg} \cdot \mathrm{kg}^{-1}\right)$, amiodarone $\left(2.0 \mathrm{mg} \cdot \mathrm{kg}^{-1}\right)$, diltiazem $\left(0.2 \mathrm{mg} \cdot \mathrm{kg}^{-1}\right)$ and nicardipine $\left(0.1 \mathrm{mg} \cdot \mathrm{kg}^{-1}\right)$. The dose of ropivacaine was $1 \mathrm{mg} \cdot \mathrm{kg}^{-1}$. A preliminary study showed that the measured blood levels $\left(1 \mu \mathrm{g} \cdot \mathrm{kg}^{-1}\right)$ were close to those seen in man after loco-regional anesthesia. ${ }^{3}$

All end-points were recorded twice at five-minute intervals prior, then one and two minutes after each AARD administration (one minute infusion), and finally one, two, five, ten, 15, 30 and $60 \mathrm{~min}$ after cessation of ropivacaine administration (one minute infusion started two minutes after the end of AARD administration).

ANOVA for repeated measurements with Greenhouse-Geisser correction was used to evidence drug and time effects. Paired $t$ tests corrected by Bonferroni for multiple samples were used to compare means of measured end-points in each group at different time points.

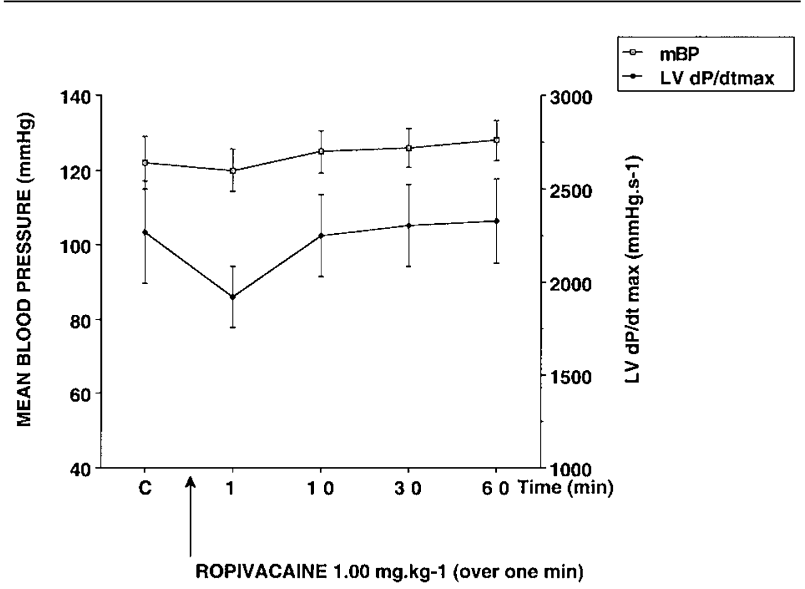

FIGURE 1 Effects of ropivacaine alone on $\mathrm{LV} \mathrm{dP} / \mathrm{dt} \max$ and mean blood pressure. Numerical values are given in Table I (available as "additional material" at www.cja-jca.org).

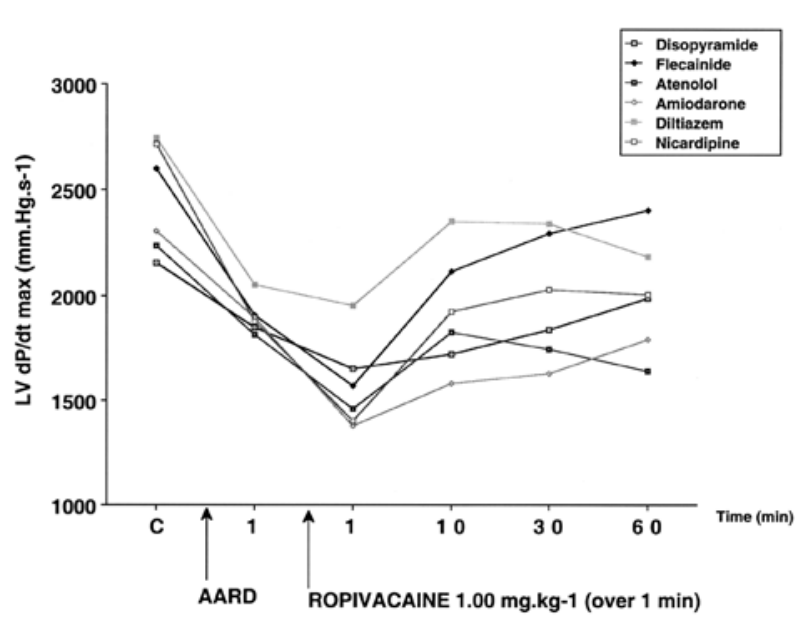

FIGURE 2 Effects of the six tested anti-arrhythmic drugs (AARD) alone and following ropivacaine administration on LV $\mathrm{dP} / \mathrm{dt} \max$. The significance and numerical values are given in Table II (available as "additional material" at www.cja-jca.org)

\section{Results}

No changes in $\mathrm{mBP}$ or $\mathrm{LVdP} / \mathrm{dt}$ max were observed in animals receiving ropivacaine alone (Figure 1 ). As expected, $\mathrm{mBP}$ and $\mathrm{LVdP} / \mathrm{dt}$ decreased after the injection of AARD. After the injection of ropivacaine, a 20 to $35 \%$ decrease in $\mathrm{LV} \mathrm{dP} / \mathrm{dt}$ max was observed in all groups. The decrease was prolonged only in animals pretreated with amiodarone (Figure 2). A brief 10 to $20 \%$ decrease in BP was observed, except in ani- 


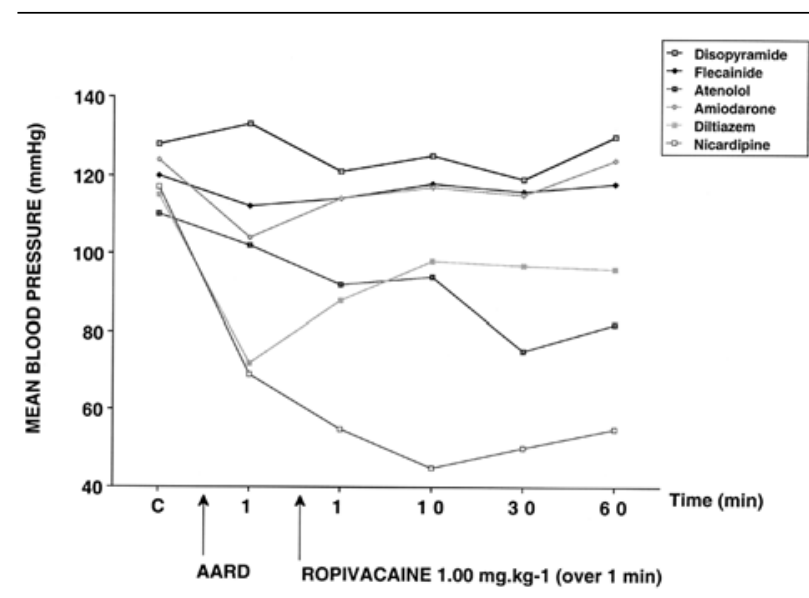

FIGURE 3 Effects of the six tested anti-arrhythmic drugs (AARD) alone and following ropivacaine administration on mean blood pressure. The significance and numerical values are given in Table II (available as "additional material" at www.cja-jca.org).

mals pretreated with nicardipine where the decrease in BP was important ans dustained (Figure 3). Detailed hemodynamic and electophysiologic results are available as "additional material" at www.cja-jca.org (Tables I and II).

\section{Discussion}

In this study, all AARD tested induced the expected hemodynamic and electrophysiologic effects. The $\mathrm{Na}^{+}$-blocking drugs disopyramide and flecainide reduce intraventricular conduction by depressing the fast sodium channel. ${ }^{4}$ Both drugs depress cardiac contractility (decreased $\mathrm{LV} \mathrm{dP} / \mathrm{dt} \max$ ) by altering the $\mathrm{Na}^{+} / \mathrm{Ca}^{++}$exchange system that plays a key role in myocyte calcium concentrations ${ }^{5}$ resulting in reduced calcium concentrations in the sarcoplasmic reticulum. The reduction in $\mathrm{LV} \mathrm{dP} / \mathrm{dt} \max$ is greater with disopyramide than with flecainide ${ }^{6}$ because disopyramide markedly increases vascular resistances. Atenolol induces bradycardia, decreases $\mathrm{BP}$ and $\mathrm{LV} \mathrm{dP} / \mathrm{dt} \max$ via its $B$-blocking effects, but produces no changes in the QT interval or QRS complexes. The amiodaronerelated decrease in $\mathrm{LV} \mathrm{dP} / \mathrm{dt} \max$ is mainly due to decreased calcium levels in the sarcoplasmic reticulum and not to decreased calcium influx. Amiodarone reduces $\mathrm{HR}$ and increases the QTc interval. As regards calcium inhibitors, Dong et al. ${ }^{7}$ found that the depression in cardiac contractility is more marked with dilti- azem than with nicardipine. Calcium inhibitors induce bradycardia without changes in the QT interval and QRS complexes.

The cardiotoxicity of local anesthetics is linked to their blood distribution, myocardial tissue binding, $\mathrm{Na}^{+}$-blocking capacities and effects on $\mathrm{Na}^{+} / \mathrm{Ca}^{++}$ exchanges. The risk of ventricular conduction contractility disorders is greater with high $\mathrm{Na}^{+}$-blocking potency (bupivacaine) and is thus lower with ropivacaine. The risk of ventricular fibrillation and other major cardiac disorders is less following ropivacaine than bupivacaine. ${ }^{8}$

Following ropivacaine, all electrophysiological endpoints remained at the level seen after the administration of each AARD. This can be explained by the relatively low $\mathrm{Na}^{+}$-blocking potency of ropivacaine. ${ }^{9}$ In contrast, the combination of ropivacaine with several AARD resulted in a markedly reduced $\mathrm{LV} \mathrm{dP} / \mathrm{dt}$ max. The negative inotropic effects of ropivacaine, although mild, ${ }^{1}$ are additive to those of AARD. Depending on the AARD, three patterns of reduction in $\mathrm{LV} \mathrm{dP} / \mathrm{dt}$ max were seen: marked and prolonged (> $30 \mathrm{~min}$ ) with amiodarone; transient (< ten minutes) but significant with disopyramide, flecainide, atenolol and nicardipine; slight and very transient with diltiazem. With diltiazem, $\mathrm{LV} \mathrm{dP} / \mathrm{dt} \max$ increased ten minutes after ropivacaine. The mechanism of the incremental reduction in $\mathrm{LV} \mathrm{dP} / \mathrm{dt}$ max by ropivacaine after the administration of AARD could involve an additive inhibition of $\mathrm{Ca}^{++}$influx with class IV AARDS, and the $\mathrm{Na}^{+} / \mathrm{Ca}^{2+}$ exchange system with the $\mathrm{Na}^{+}$blocking disopyramide and flecainide. An inhibition of $3^{\prime}, 5^{\prime}$-AMPc production by ropivacaine is another possibility. ${ }^{10}$ This inhibition could be mediated by receptor-operated channels resulting in decreased intracellular calcium concentrations resulting in reduced cardiac contractility. The blockade of $\mathrm{Ca}^{++}$influx through voltage-dependent calcium channels by calcium inhibitors inhibits the signal required by the sarcoplasmic reticulum to release stored $\mathrm{Ca}^{++}$. The lack of effects of the ropivacaine-diltiazem combination on cardiac contractility could be due to improved hemodynamic conditions as suggested by the reduced bradycardia and increased BP.

In conclusion, this study in pigs demonstrates that ropivacaine combined to various AARD induces no significant electrophysiological changes. In most cases, alterations in cardiac contractility were mild and transient, except with amiodarone (decreased $\mathrm{LV} \mathrm{dP} / \mathrm{dt}$ $\max$ ) and nicardipine (decreased BP). Careful per-and postsurgical follow-up of patients is recommended in patients treated with either amiodarone or nicardipine following ropivacaine administration. 


\section{Acknowledgements}

The study was funded by a grant from EA 1896. The authors acknowledge the assistance of $\mathrm{B}$. Tourlières for the literature search.

\section{References}

1 Scott DB, Lee A, Fagan D, Bowler GM, Bloomfield P, Lundh $R$. Acute toxicity of ropivacaine compared with that of bupivacaine. Anesth Analg 1989; 69: 563-9.

2 Timour Q, Freysz M, Lang J, et al. Electrophysiological study in the dog of the risk of cardiac toxicity of bupivacaine. Arch Int Pharmacodyn Ther 1987; 287: 65-77.

3 Wulf $H$, Worthmann F, Behnke H, Boble AS.

Pharmacokinetics and pharmacodynamics of ropivacaine $2 \mathrm{mg} / \mathrm{mL}, 5 \mathrm{mg} / \mathrm{mL}$, or $7.5 \mathrm{mg} / \mathrm{mL}$ after illioinguinal blockade for inguinal hernia repair in adults. Anesth Analg 1999; 89: 1471-4.

4 Hodess AB, Follansbee WP, Spear JF, Moore EN.

Electrophysiological effects of a new antiarrhythmic agent, flecainide, on the intact canine heart. J Cardiovasc Pharmacol 1979; 1: 327-39.

5 Elias CL, Lukas A, Shurraw S, et al. Inhibition of $\mathrm{Na}^{+} / \mathrm{Ca}^{2+}$ exchange by KB-R7943: transport mode selectivity and antiarrhythmic consequences. Am J Physiol Heart Circ Physiol 2001; 281: H1334-45.

6 Hoffmeister HM, Hepp A, Seipel L. Negative inotropic effect of class-I-antiarrhythmic drugs: comparison of flecainide with disopyramide and quinidine. Eur Heart J 1987; 8: 1126-32.

7 Dong $H$, Earle $M L$, Jiang $\Upsilon$, Loutzenhiser KA, Triggle $C R$. Cardiovascular effects of CPU-23, a novel L-type calcium channel blocker with a unique molecular structure. Br J Pharmacol 1997; 122: 1271-8.

8 Reiz $S$, Haggmark $S$, Johansson $G$, Nath $S$. Cardiotoxicity of ropivacaine-a new amide local anaesthetic agent. Acta Anaesthesiol Scand 1989; 33: 93-8.

9 Arlook P. Actions of three local anaesthetics: lidocaine, bupivacaine and ropivacaine on guinea pig papillary muscle sodium channels $\left(\mathrm{V}_{\max }\right)$. Pharmacol Toxicol 1988; 2: 96-104.

10 Butterworth JF 4th, Brownlow RC, Leith JP, Prielipp $R C$, Cole LR. Bupivacaine inhibits cyclic-3'5'-adenosine monophosphate production. A possible contributing factor to cardiovascular toxicity. Anesthesiology 1993; 79: 88-95. 